University of Nebraska - Lincoln

DigitalCommons@University of Nebraska - Lincoln

2010

\title{
Acute caffeine consumption enhances the executive control of visual attention in habitual consumers
}

\author{
Tad T. Brunyé \\ US Army Natick Soldier Research, tbruny01@tufts.edu \\ Caroline R. Mahoney \\ Tufts University \\ Harris R. Lieberman \\ US Army Research Institute for Environmental Medicine \\ Grace E. Giles \\ US Army Natick Soldier Research \\ Holly A. Taylor \\ Tufts University
}

Follow this and additional works at: https://digitalcommons.unl.edu/usarmyresearch

Part of the Operations Research, Systems Engineering and Industrial Engineering Commons

\footnotetext{
Brunyé, Tad T.; Mahoney, Caroline R.; Lieberman, Harris R.; Giles, Grace E.; and Taylor, Holly A., "Acute caffeine consumption enhances the executive control of visual attention in habitual consumers" (2010). US Army Research. 115.

https://digitalcommons.unl.edu/usarmyresearch/115

This Article is brought to you for free and open access by the U.S. Department of Defense at DigitalCommons@University of Nebraska - Lincoln. It has been accepted for inclusion in US Army Research by an authorized administrator of DigitalCommons@University of Nebraska - Lincoln.
} 


\title{
Acute caffeine consumption enhances the executive control of visual attention in habitual consumers
}

\author{
Tad T. Brunyé ${ }^{\mathrm{a}, \mathrm{b}, *}$, Caroline R. Mahoney ${ }^{\mathrm{a}, \mathrm{b}}$, Harris R. Lieberman ${ }^{\mathrm{c}}$, Grace E. Giles ${ }^{\mathrm{a}, \mathrm{b}}$, Holly A. Taylor ${ }^{\mathrm{b}}$ \\ ${ }^{a}$ US Army Natick Soldier Research, Development and Engineering Center, Kansas St., Natick, MA, USA \\ ${ }^{\mathrm{b}}$ Tufts University, Department of Psychology, 490 Boston Ave., Medford, MA, USA \\ ${ }^{\mathrm{c}}$ US Army Research Institute for Environmental Medicine, Kansas St., Natick, MA, USA
}

\section{A R T I C L E I N F O}

\section{Article history:}

Accepted 22 July 2010

Available online 15 September 2010

\section{Keywords:}

Caffeine

Arousal

Attention networks

Visuospatial attention

\begin{abstract}
A B S T R A C T
Recent work suggests that a dose of $200-400 \mathrm{mg}$ caffeine can enhance both vigilance and the executive control of visual attention in individuals with low caffeine consumption profiles. The present study seeks to determine whether individuals with relatively high caffeine consumption profiles would show similar advantages. To this end, we examined the effects of four caffeine doses $(0 \mathrm{mg}, 100 \mathrm{mg}, 200 \mathrm{mg}, 400 \mathrm{mg})$ on low- and high-level visual attention in individuals with high consumption profiles $(n=36)$, in a double-blind study using a repeated measures design. Results from the Attention Network Test indicated that caffeine enhanced both vigilance and the executive control of visual attention, but only at the highest administered dose $(400 \mathrm{mg}$ ). We demonstrate that in habitual consumers high doses of caffeine can produce beneficial changes in visual attention. These results carry implications for the theorized interactions between caffeine, adenosine and dopamine in brain regions mediating visual attention.
\end{abstract}

Published by Elsevier Inc.

\section{Introduction}

Caffeine (1,3,7-trimethylxanthine) is the most commonly consumed psychoactive stimulant in the world, and is often found to enhance human vigilance and mental alertness (Lieberman, 2001; Nehlig, Daval, \& Debry, 1992; Smith, 2002; Snel, Lorist, \& Tieges, 2004). For instance, individuals are able to sustain visual vigilance for extended periods following caffeine consumption (Frewer \& Lader, 1991; Lieberman, Wurtman, Emde, Roberts, \& Coviella, 1987; Mitchell \& Redman, 1992), and also show dosedependent performance improvements in accuracy and speeded responses on simple and choice reaction time tasks (Kenemans \& Lorist, 1995; Lieberman, Tharion, Shukitt-Hale, Speckman, \& Tulley, 2002; Wesensten, Killgore, \& Balkin, 2005). Caffeine has also been implicated in the enhancement of certain higher-order cognitive processes, such as those involved in the active monitoring and coordination of behavior. For instance, caffeine can reduce response time costs during task switching (Tieges, Snel, Kok, Plat, \& Ridderinkhof, 2007; Tieges et al., 2006), enhance response inhibition (Barry et al., 2007), and reduce interference costs during the Stroop color-word, flanker, and other selective visual attention tasks (Brunyé, Mahoney, Lieberman, \& Taylor, 2010; Kenemans,

\footnotetext{
* Corresponding author. Address: US Army Natick Soldier Research, Development and Engineering Center, Cognitive Science, 15 Kansas St., Natick, MA 01760, USA.

E-mail address: tbruny01@tufts.edu (T.T. Brunyé).
}

Weileman, Zeegers, \& Verbaten, 1999; Lorist, Snel, Kok, \& Mulder, 1996). The effects of caffeine on such higher-order tasks, however, are somewhat equivocal; indeed some other recent work suggests that caffeine does not affect selective visual attention (Kenemans \& Verbaten, 1998; Lorist \& Snel, 1997) or response inhibition (Tieges, Snel, Kok, \& Ridderinkhof, 2009).

There are many methodological differences between these studies that may account for the discrepant findings. First, studies finding no effect of caffeine on higher-order tasks (e.g., Kenemans \& Verbaten, 1998; Lorist \& Snel, 1997; Tieges et al., 2009) typically use a $3 \mathrm{mg} / \mathrm{kg}$ dose (approx. $200 \mathrm{mg}$ ) of caffeine in individuals with high caffeine consumption profiles. However, the effective dosage to elicit changes in higher-order cognitive processes may be greater in individuals who habitually consume 2-4 cups of coffee (170$340 \mathrm{mg}$ caffeine) per day (Juliano \& Griffiths, 2004; Kenemans et al., 1999). Indeed chronic caffeine consumption increases the number of adenosine receptors in the brain, suggesting that higher caffeine doses may be necessary to achieve substantial dopamine increases in high consumers (Daval, von Lubitz, Deckert, Redmond, \& Marangos, 1989; Fastbom, Post, \& Fredholm, 1990; Varani et al., 1999). Second, caffeine effects tend to be greatest on highly practiced tasks (Loke, 1992), and thus some null effects may be partially attributed to the lack of a substantial practice session (Kenemans \& Verbaten, 1998; Lorist \& Snel, 1997). The present study accounts for these methodological issues in two ways. First, we use a more comprehensive dose-response design with four 
levels of caffeine ( $0 \mathrm{mg}, 100 \mathrm{mg}, 200 \mathrm{mg}, 400 \mathrm{mg}$ ) in participants with high caffeine consumption profiles (i.e., $\geqslant 500 \mathrm{mg}$ per day); we hypothesize that $200 \mathrm{mg}$ may not be sufficient to modulate higher-order cognitive processes related to the control of visual attention (Tieges et al., 2009), but a $400 \mathrm{mg}$ dose may produce significant effects. Our design allows a test of this hypothesis. Second, we provide participants with multiple practice sessions to increase task familiarity and reduce training effects across sessions.

With this improved design, there are several reasons to expect caffeine to modulate higher-order cognitive processes, particularly the effortful control of visual attention. Studies have demonstrated that caffeine reduces response conflicts in the classic Stroop colorword task (Hasenfratz \& Battig, 1992; Kenemans et al., 1999). Further, meta-analyses of Stroop-related brain activation have detailed a network of brain areas, including the anterior cingulate cortex (ACC), as responsible for successful control of visual attention (Bush, Luu, \& Posner, 2000; Bush et al., 1998). In fact, many studies have identified the ACC's critical importance for successful control of visual attention across a variety of tasks (Botvinick, Braver, Barch, Carter, \& Cohen, 2001; Casey et al., 2000; Fan, Flombaum, McCandliss, Thomas, \& Posner, 2003; Mac Donald, Cohen, Stenger, \& Carter, 2000). The ACC receives one of the highest levels of dopaminergic innervation in the brain (Lumme, Aalto, Ilonen, Någren, \& Hietala, 2007), and caffeine is a highly reliable catalyst for dopaminergic availability through its antagonistic effects on adenosine (Garrett \& Griffiths, 1997; Popoli, Reggio, Pezzola, Fuxe, \& Ferré, 1998; Solinas et al., 2002). In support of this position, there is recent neuroimaging evidence demonstrating that the ACC is reliably up-regulated by caffeine consumption (Koppelstaetter et al., 2008). Given these relationships between caffeine, adenosine, dopamine, the ACC and executive function, we expect that high doses of caffeine may enhance the effortful control of visual attention.

\section{The present study}

Given the high and increasing prevalence of caffeine consumption (Malinauskas, Aeby, Overton, Carpenter-Aeby, \& BarberHeidal, 2007; Reissig, Strain, \& Griffiths, 2009), it is critical to understand how the growing population of habitual consumers might show modulation of executive control as a function of acute caffeine consumption. Indeed earlier results with relatively low frequency consumers may not be generalizable to samples with consumption profiles that better reflect caffeine's prevalence. To this end, the present study assessed how four doses of our Treatment variable ( $0 \mathrm{mg}, 100 \mathrm{mg}, 200 \mathrm{mg}, 400 \mathrm{mg}$ caffeine) would affect habitual consumers' performance on the Attention Network Test (ANT; Fan, McCandliss, Sommer, Raz, \& Posner, 2002). The ANT is a composite task that reliably tests the independent functioning of three theorized (Posner, 1990) visual attention networks: alerting, orienting, and executive control (Fan et al., 2002, 2003; Neuhaus et al., 2007; Posner \& Rothbart, 2005).

Alerting involves achieving and maintaining a state of alertness (vigilance) during task performance; the ANT tests the functioning of this network by assessing the utility of predictive cues regarding trial onset. Neuroimaging studies demonstrate that alerting cues activate the thalamus and bilateral frontal and parietal brain regions (Fan, McCandliss, Fossella, Flombaum, \& Posner, 2005; Marrocco \& Davidson, 1998); given that the thalamus and prefrontal cortex receive dense dopaminergic innervation (SánchezGonzález, García-Cabezas, Rico, \& Cavada, 2005; Williams \& Goldman-Rakic, 1995), we expected that alerting would be improved as a function of caffeine dose. This hypothesis is in line with studies demonstrating improvement in basic psychomotor speed and vigilance performance in a positive dose-response relationship with caffeine consumption (for reviews, see Koelega, 1993; Lieberman, 1992, 2001; Smith, 2002; Snel et al., 2004; Spiller, 1997).

Orienting involves selectively attending to cued regions of space in anticipation of stimulus onset; the ANT tests the functioning of this network by assessing the utility of predictive relative to non-predictive spatial cues regarding an upcoming trial location. Neuroimaging studies demonstrate that orienting involves the activation of the superior parietal lobe (Corbetta, Kincade, Ollinger, McAvoy, \& Shulman, 2000; Fan et al., 2005). Given sparse dopaminergic innervations of the parietal lobes (Lidow, Goldman-Rakic, Rakic, \& Innis, 1989; Tassin et al., 1978), and recent work demonstrating only marginal effects of caffeine on orienting function in low caffeine consumers (Brunyé et al., 2010), we expected that caffeine consumption would not affect orienting function in a sample of habitual consumers.

The executive control of visual attention involves the resolution of conflicts between potential responses to a presented stimulus; the ANT tests the functioning of this network by assessing response time decrements produced as a function of response-incongruent information flanking a target stimulus. Neuroimaging studies demonstrate that this type of visual executive control process activates the anterior cingulate cortex (ACC) and lateral prefrontal cortices (Botvinick et al., 2001; Bush et al., 2000; Casey et al., 2000; Fan et al., 2005). Given recent work demonstrating improvement in visual executive control in low consumers (Brunyé et al., 2010), dense dopaminergic innervations in the ACC and prefrontal brain regions (Lumme et al., 2007), and the fact that dopamine binding in the ACC moderates executive function (Ko et al., 2009), we expected that a high dose (e.g., $400 \mathrm{mg}$ ) of caffeine would produce similar effects in individuals with high consumption profiles.

For both alerting and executive control, a competing hypothesis is offered by research demonstrating increased adenosine receptor densities in the habitual consumer brain (Daval et al., 1989; Fastbom et al., 1990; Varani et al., 1999), which may limit the dopaminergic response to our range of caffeine doses. If this is the case, then results will not demonstrate modulation of executive control as a function of caffeine dosage.

\section{Method}

\subsection{Participants}

Thirty-six high caffeine consuming ( $M=592.3 \mathrm{mg} /$ day) undergraduate students (10 male; mean age 20.11 ; mean BMI 23.06) participated for monetary compensation ( $\$ 10 \mathrm{USD} / \mathrm{h})$. All participants were non-nicotine users, in good health, and did not use prescription medication other than oral contraceptives. Written informed consent was obtained, and all procedures were jointly approved by the Tufts University Institutional Review Board and the Human Use Review Committee of the US Army Research Institute for Environmental Medicine.

\subsection{Design}

We used a within-participants design with four levels of a double-blind independent variable, Treatment $(0 \mathrm{mg}, 100 \mathrm{mg}, 200 \mathrm{mg}$, $400 \mathrm{mg}$ caffeine). The $400 \mathrm{mg}$ dose was chosen given that $20 \mathrm{oz}$ coffees sold at major franchise coffee houses typically contain from 350 to $450 \mathrm{mg}$ caffeine (McCusker, Goldberger, \& Cone, 2003). Caffeine (99.8\% pure anhydrous USP-grade powder) and placebo (physiologically inert microcrystalline cellulose powder) were administered in identical capsule form with water, and Treatment order was counterbalanced across participants in a Latin square. 


\subsection{Materials}

\subsubsection{Manipulation check}

To assess the effectiveness of caffeine in modulating participant affective arousal, we administered the Brief Mood Introspection Scale (BMIS; Mayer \& Gaschke, 1988) both pre-caffeine and postmetabolism. This scale involves rating a series of 16 affective adjectives (e.g., peppy, tired, active, calm) on scales that range from 1 (definitely do not feel) to 4 (definitely feel).

\subsubsection{Attention Network Test}

The ANT involves responding to the direction of a central arrow that faces either left or right. On some trials the presentation of the arrow is preceded by cues that alert participants to the onset of a trial, and on some trials participants also receive a cue that orients them to a particular region of the screen (above or below fixation). The central arrow appears with two flanking stimuli on either side, either in the form of neutral lines or arrows facing either a congruent or incongruent direction relative to the central arrow. Accuracy and response time are measured when the participant responds to the facing direction of the central arrow. Alerting is measured as the extent to which a cue can alert the participant to trial onset, relative to when no cue is provided. Orienting is measured as the extent to which a spatially-determinate cue can orient a participant to the appropriate screen region where the central arrow will appear (above or below fixation) relative to when a spatiallyindeterminate cue is provided. Executive control is measured as the extent to which incongruent flanking arrows interfere with a participant's response relative to when flanking arrows are congruent with the facing direction of the central arrow. The ANT involves three blocks of 96 trials each, presented in random order; for a more complete task description refer to Fan et al. (2002). Participants are instructed to respond to the facing direction of the central arrow as quickly and accurately as possible; they are also told that on certain trials they would receive cues that indicate when the trial was about to begin (alerting) and/or where it would appear on the screen (orienting).

\subsection{Procedure}

Participants visited the laboratory on five separate sessions, each separated by at least 3 days: one normal consumption session and four test sessions. All sessions took place in the morning at a consistent time within participants. During the normal consumption session, participants practiced a full version of the ANT and completed all tasks in the same order as during the test sessions; for this session only, participants were instructed to consume their normal amounts of caffeine prior to coming to the laboratory, and did not consume a capsule. The four subsequent test sessions followed a 12-h water-only fast wherein participants were instructed not to consume any substance other than water; note that a $12-\mathrm{h}$ fast is a sufficient wash-out period for caffeine given research demonstrating mean plasma and elimination half-lives of $2.5-5 \mathrm{~h}$ in healthy participants (Arnaud, 1987; Culm-Merdek, von Moltke, Harmatz, \& Greenblatt, 2005; IOM, 2001; Statland \& Demas, 1980). Participants were instructed not to use any over-thecounter medications or herbal supplements for $24 \mathrm{~h}$ prior to testing; to encourage compliance with these instructions we collected saliva samples upon arrival for each test session (not further analyzed herein; see also Brunyé et al., 2010; Tieges et al., 2009).

During each test session, participants completed the BMIS upon arrival, provided a saliva sample, consumed their assigned Treatment capsule along with a cup of water, and took a 20-min break (to allow for sufficient plasma concentrations of caffeine; Arnaud, 1987). They then completed a 3-min practice session of the ANT, performed the full ANT (approximately $15 \mathrm{~min}$ ), and then again completed the BMIS.

\section{Results}

Two participants were removed from further analysis for not completing the ANT during one or more test sessions.

\subsection{Self-reported mood state}

We performed a repeated-measures ANOVA on adjective ratings following caffeine consumption. As detailed in Table 1, we confirmed the effectiveness of our Treatment manipulation, with significant increases in participants' ratings of how Lively, Jittery, Peppy, Nervous and Active they felt as a function of Treatment level; conversely, there were significant decreases in ratings of Tired, Drowsy, and Calm. Table 1 lists Dunnett's test (comparing each dose to the $0 \mathrm{mg}$ condition) results for adjectives with significant ANOVA effects.

\subsection{Attention Network Test}

\subsubsection{Treatment effects on Attention Networks}

To evaluate the effect of caffeine on ANT performance, we calculated difference scores (i.e., Fan et al., 2002, 2005; Redick \& Engle, 2006) to independently assess the functioning of each attention network: alerting, orienting, and executive control. Alerting difference scores were calculated by subtracting mean RTs during trials with double-cue configuration from mean RTs from trials with no cues (higher scores indicate more efficient alerting function). Orienting difference scores were calculated by subtracting mean RTs during spatial cue trials (top versus bottom cue) from trials with a center cue only (higher scores indicate more efficient orienting function). Finally, executive control scores were calculated by subtracting mean RTs during congruent flanker trials (i.e., flanking arrows matching facing direction of central arrow) from trials with incongruent flankers (i.e., flanking arrows mismatching facing direction of central arrow); lower executive control difference scores indicate more efficient executive control function. Fig. 1 depicts each of these three difference scores as a function of caffeine Treatment levels.

For all analyses, effect sizes are denoted using Cohen's $d$ and eta-squared $\left(\eta^{2}\right)$. To analyze difference scores as a function of

Table 1

BMIS adjective ratings as a function of Treatment dosage.

\begin{tabular}{|c|c|c|c|c|c|c|c|c|}
\hline \multirow[t]{3}{*}{ Adjective } & \multicolumn{8}{|c|}{ Treatment } \\
\hline & \multicolumn{2}{|c|}{$0 \mathrm{mg}$} & \multicolumn{2}{|c|}{$100 \mathrm{mg}$} & \multicolumn{2}{|c|}{$200 \mathrm{mg}$} & \multicolumn{2}{|c|}{$400 \mathrm{mg}$} \\
\hline & $M$ & $S D$ & $M$ & $S D$ & $M$ & $S D$ & $M$ & $S D$ \\
\hline Lively & 2.29 & .68 & 2.62 & .60 & $2.82^{*}$ & .63 & $2.74^{*}$ & .83 \\
\hline Happy & 2.85 & .61 & 2.94 & .69 & 2.76 & .69 & 2.82 & .72 \\
\hline Sad & 1.82 & .52 & 1.74 & .57 & 1.71 & .63 & 1.71 & .58 \\
\hline Tired & 3.14 & .56 & $2.74^{*}$ & .89 & $2.65^{*}$ & .88 & $2.76^{*}$ & 1.05 \\
\hline Caring & 2.62 & .69 & 2.68 & .77 & 2.79 & .69 & 2.68 & .64 \\
\hline Content & 2.85 & .66 & 3.03 & .72 & 2.88 & .73 & 2.88 & .59 \\
\hline Gloomy & 1.76 & .69 & 1.73 & .67 & 1.97 & .83 & 1.79 & .77 \\
\hline Jittery & 1.82 & .72 & 1.74 & .67 & 1.94 & .81 & $2.29^{*}$ & .91 \\
\hline Drowsy & 2.79 & .73 & 2.44 & .93 & $2.35^{*}$ & .77 & $2.26^{*}$ & 1.08 \\
\hline Grouchy & 1.82 & .76 & 1.82 & .63 & 1.88 & .81 & 1.85 & .78 \\
\hline Peppy & 2.00 & .74 & 2.18 & .79 & 2.09 & .87 & $2.47^{*}$ & .86 \\
\hline Nervous & 1.97 & .72 & 1.79 & .64 & 2.00 & .85 & 2.26 & .86 \\
\hline Calm & 3.03 & .63 & 3.00 & .63 & 2.91 & .71 & $2.65^{*}$ & .77 \\
\hline Loving & 2.56 & .61 & 2.56 & .79 & 2.56 & .75 & 2.59 & .82 \\
\hline Fed Up & 2.11 & .91 & 1.94 & .81 & 1.91 & .71 & 1.88 & .77 \\
\hline Active & 2.26 & .67 & $2.53^{*}$ & .71 & 2.41 & .70 & $2.56^{*}$ & .70 \\
\hline
\end{tabular}

Significant Dunnett's test results, comparing Treatment level to $0 \mathrm{mg}$ placebo. 


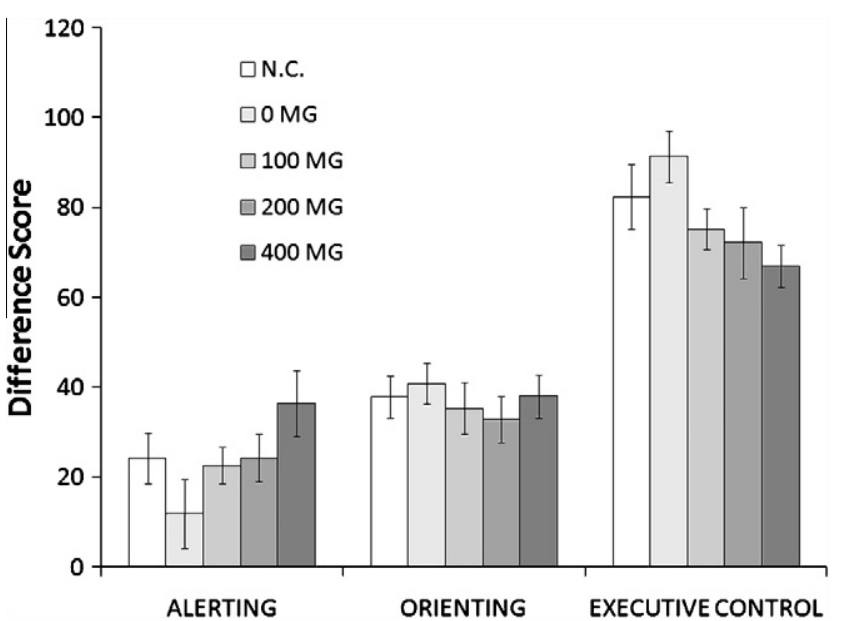

Fig. 1. Mean difference scores and standard errors for each of the three attention networks and four Treatment levels. Note that higher difference scores in the alerting and orienting networks indicate greater performance; conversely, lower difference scores in the executive control network indicate greater performance. N.C. $=$ normal consumption.

Treatment ( $0 \mathrm{mg}, 100 \mathrm{mg}, 200 \mathrm{mg}, 400 \mathrm{mg}$ caffeine), we conducted three separate single-factor repeated-measures ANOVAs, one for each attention network. Analysis of alerting difference scores demonstrated a marginal effect of Treatment, $F(3,99)=2.19, p=.09$, $\eta^{2}=.06$. Comparisons using the Dunnett's test (comparing each dose to the $0 \mathrm{mg}$ condition) revealed higher alerting difference scores in the $400 \mathrm{mg}$ condition, $t_{d}(33)=2.56, p<.05, d=.36$ (all other $p$ 's $>.05$ ). Analysis of orienting difference scores did not reveal an effect of Treatment, $F(3,99)=.60, p>.05, \eta^{2}=.02$. Finally, analysis of executive control difference scores revealed an effect of Treatment, $F(3,99)=3.75, p<.05, \eta^{2}=.10$; comparisons using the Dunnett's test revealed lower difference scores in the $400 \mathrm{mg}$ condition, $t_{d}(33)=3.17, p<.01, d=.60$ (all other $p$ 's $\left.>.05\right)$.

\subsubsection{Testing for withdrawal effects}

To rule out the possibility that our results could be solely attributed to performance reduction on the $0 \mathrm{mg}$ day (due to withdrawal), we conducted three $t$-tests comparing the normal consumption day to the $0 \mathrm{mg}$ day (one for each attention network difference score). Though withdrawal led to numerically poorer performance for all three attention networks at the $0 \mathrm{mg}$ dose relative to the normal consumption day (cf., Lane \& Phillips-Bute, 1998), no analysis of those differences reached statistical significance: alerting scores, $t(33)=1.39, p>.05$, orienting scores, $t(33)=.65, p>.05$, and executive control scores, $t(33)=1.16, p>.05$. The lack of significant withdrawal effects is likely due to average consumption rates being influenced by consumption throughout the day, whereas all laboratory sessions occurred in the morning (cf., Fredholm, Bättig, Holmén, Nehlig, \& Zvartau, 1999).

\section{Discussion}

The present study extended previous work examining caffeine effects on lower- and higher-level visual attention by using a more comprehensive dose-response design, an integrated and reliable attention task, and an extended practice session. Whereas we cannot be certain that the exclusion of a practice session would negate our effects, our dose-response design did allow for a direct comparison of a commonly used dose ( $200 \mathrm{mg}$ ) with a substantially higher dose (400 mg) in a sample of high consumers. As hypothesized, $200 \mathrm{mg}$ was not sufficient to modulate lower- or higher- order cognitive processes related to the deployment and control of visual attention
(Tieges et al., 2009), but a $400 \mathrm{mg}$ dose produced significant effects. We specifically detail our results and discuss implications below as a function of the three attention networks under examination: alerting, orienting, and executive control.

\subsection{Alerting}

The alerting network is theorized to be responsible for achieving and maintaining vigilance and alertness during the performance of continuous task (Fan et al., 2002; Posner, 1990, 2004). Functional neuroimaging studies demonstrate that successful alerting recruits the prefrontal cortex and thalamus (Fan et al., 2005), two brain areas that receive dense dopaminergic innervations. In fact, the thalamus is one of the few brain areas with colocated adenosine (A2A) and dopamine (D2) receptors (i.e., Fink et al., 1992). Given that caffeine reliably up-regulates dopaminergic availability through its inhibitory effects on adenosine, we expected that a high dose of caffeine would improve alerting performance in high consumers; our results partially support this hypothesis. Alerting difference scores showed overall increases as a function of caffeine dose, though only at the $400 \mathrm{mg}$ dose did the increase become significant relative to placebo. Presently, it could be the case that high habitual caffeine consumption levels may increase requisite doses to achieve substantial alerting effects; in fact, our earlier work examining the ANT found effects of caffeine on alerting functioning at both $200 \mathrm{mg}$ and $400 \mathrm{mg}$ when examining non-habitual caffeine consumers (Brunyé et al., 2010). Overall, the results from both habitual and non-habitual consumers support a large body of literature demonstrating caffeine's positive influence on lower-level visual attention and psychomotor tasks (Frewer \& Lader, 1991; Kenemans \& Lorist, 1995; Lieberman et al., 1987, 2002; Mitchell \& Redman, 1992; Wesensten et al., 2005), but underscore the importance of examining these effects in a range of participant consumption profiles.

\subsection{Orienting}

The orienting network allows individuals to use cues to selectively orient attention to particular regions of space in preparation for an upcoming stimulus. Functional neuroimaging studies demonstrate that the orienting network is primarily the locus of the superior parietal lobe (i.e., Corbetta et al., 2000; Fan et al., 2005), a brain area thought to have relatively low dopamine innervation in humans and other animals (Lidow et al., 1989; Tassin et al., 1978). Given that the behaviorally significant effects of caffeine on the central nervous system are thought to result primarily from its direct effects on adenosine (at $\mathrm{A}_{1}$ and $\mathrm{A}_{2 \mathrm{~A}}$ receptors) and indirect effects on dopaminergic availability (Cropley, Fujita, Innis, \& Nathan, 2006; Fredholm, 1980, 1995; Varani et al., 1999), we expected that caffeine would not affect orienting function. Our results support this hypothesis, providing no evidence that caffeine affects orienting function, somewhat in line with recent results found with low consumers (Brunyé et al., 2010). In this earlier research, we identified marginal effects of caffeine on orienting system functioning (at $400 \mathrm{mg}$ ); we propose that caffeine has only minor effects on the orienting of attention, and that these effects only occur at high doses in participant samples with low consumption profiles. Further, these results support the notion that caffeine-induced changes in cognitive performance may be related more to its effects on dopaminergic rather than noradrenergic systems (i.e., Fredholm et al., 1999; Garrett \& Griffiths, 1997; Lorist \& Tops, 2003; Nehlig, 1999; Tieges, Ridderinkhof, Snel, \& Kok, 2004); indeed whereas the parietal lobes are not densely innervated by dopamine, they are a fundamental component of the brain's norepinephrine system (Coull, Frith, Frackowiak, \& Grasby, 1996; Marrocco, Witte, \& Davidson, 1994). If the noradrenergic effects 
of caffeine (via adenosine) affect visual attention, then one might expect to see such an effect during the orienting of attention.

\subsection{Executive control network}

The executive control network allows individuals to reduce the performance degradation typically seen with action-incompatible visual information (i.e., incongruent relative to congruent or neutral flanker arrows; Posner, 1990, 2004). Functional neuroimaging studies have demonstrated that the executive control of visual attention recruits both the anterior cingulate and prefrontal cortex (Botvinick et al., 2001; Bush et al., 1998, 2000; Casey et al., 2000; Fan et al., 2003; Mac Donald, Cohen, Stenger, \& Carter, 2000). Given that these areas are typically up-regulated by caffeine consumption (Koppelstaetter et al., 2008), and executive function in these areas is thought to be supported by dopaminergic availability (Ko et al., 2009), we expected that a high dose of caffeine would enhance the executive control of visual attention. Congruent with recent findings examining ANT performance in low consumers (Brunyé et al., 2010), we identified dose-dependent increases in the ability to inhibit action-incompatible information; this effect only reached significance at a dose exceeding that used in prior studies (i.e., $400 \mathrm{mg}$ ). As a reminder, lower executive control difference scores indicate higher functioning (see Fig. 1). Our findings highlight the importance of examining a broad range of doses when examining habitual high consumer populations. Due at least to higher adenosine receptor density in habitual caffeine consumers (Daval et al., 1989; Fastbom et al., 1990; Varani et al., 1999), higher doses may be required to elicit substantial effects of caffeine on adenosine inhibition and dopamine availability.

The present effect on executive control also may speak to the distinction between reactive and active inhibition (Fillmore \& Rush, 2002). Active inhibition involves actively and deliberately inhibiting thoughts and actions, such as immediately aborting a learned response (i.e., stop-signal task; Logan \& Cowan, 1984), or switching task sets (i.e., Monsell, 2003). In contrast, reactive inhibition involves interference control mechanisms during a relatively automated process (i.e., De Jong, Liang, \& Lauber, 1994), such as inhibiting an inappropriate response when a flanking stimulus mismatches a target stimulus (i.e., incongruent versus congruent flanker trials). Though our design does not specifically allow for a dissociation of active and reactive inhibition, our findings support a growing consensus that caffeine may enhance reactive inhibition (Hasenfratz \& Battig, 1992; Kenemans et al., 1999; Lorist, Snel, Kok, \& Mulder, 1994; Lorist et al., 1996), unlike results found with active inhibition (e.g., Barry et al., 2007; Tieges et al., 2009). Some recent evidence suggests that active inhibition may bypass the striatum (Aron \& Poldrack, 2006), which holds one of the highest adenosine receptor densities in the brain (Fredholm et al., 1999) and is thought to be of greater importance for reactive relative to active inhibition (Cropley et al., 2006).

\section{Conclusions}

The present study identified effects of caffeine on performance during a modified flanker task designed to measure the relative function of the alerting, orienting and executive control networks. In general, caffeine improves the efficiency with which participants can take advantage of cues that alert them to trial onset, and further improves their ability to efficiently inhibit the influence of action-incompatible stimuli. In the present high consumer participant sample, these effects only occurred at the highest caffeine dose $(400 \mathrm{mg})$ and did not appear to be attributable to withdrawal effects.
The effect on alerting supports several decades of research demonstrating the positive effects of caffeine on tasks requiring speeded responses and continuous vigilance (e.g., Fine et al., 1994; Kenemans \& Lorist, 1995; Lieberman et al., 2002; Wesensten et al., 2005). Caffeine's effects on such lower-level attention tasks are likely due to its antagonistic role at adenosine $A_{1}$ and $A_{2 A}$ receptors in areas with high concentrations of dopaminergic innervation; the up-regulation of dopamine in frontal and thalamic brain regions is thought to result in increased feelings of wakefulness and pronounced motor activity, ultimately improving performance on tasks requiring speeded responses (i.e., Garrett \& Griffiths, 1997; Popoli et al., 1998; Solinas et al., 2002). A high dose of caffeine also improved the executive control of visual attention, supporting recent work with non-habitual caffeine consumers (Brunyé et al., 2010), and demonstrating caffeine's positive effects on tasks requiring reactive inhibition. These effects are likely attributed to dopamine effects on brain areas responsible for successful inhibitory control of attention, such as the anterior cingulate, striatum, and prefrontal cortex (Coull et al., 1996; Cropley et al., 2006; Fan et al., 2005; Ferre, Fredholm, Morelli, Popoli, \& Fuxe, 1997; Fredholm et al., 1999; García-Cabezas, Rico, SánchezGonzález, \& Cavada, 2007; Sawaguchi \& Goldman-Rakic, 1991, 1994; Smits et al., 1987; Sánchez-González et al., 2005; Williams \& Goldman-Rakic, 1995).

Caffeine is the most popular and widely-consumed psychoactive stimulant in the world, and carries diverse implications for central nervous system function. Its prevalence underscores the importance of understanding the breadth of its effects at a range of doses in both high- and low-consumers. We add to a growing body of evidence suggesting that caffeine can have varied and substantial effects on the deployment and control of visual attention.

\section{References}

Arnaud, M. J. (1987). The pharmacology of caffeine. Progress in Drug Research, 31, 273-313.

Aron, A. R., \& Poldrack, R. A. (2006). Cortical and subcortical contributions to stop signal response inhibition: Role of the subthalamic nucleus. Journal of Neuroscience, 26(9), 2424-2433.

Barry, R. J., Johnstone, S. J., Clarke, A. R., Rushby, J. A., Brown, C. R., \& McKenzie, D. N. (2007). Caffeine effects on ERPs and performance in an auditory Go/NoGo task. Clinical Neurophysiology, 118, 2692-2699.

Botvinick, M. M., Braver, T. S., Barch, D. M., Carter, C. S., \& Cohen, J. D. (2001). Conflict monitoring and cognitive control. Psychological Review, 108(3), 624-652.

Brunyé, T. T., Mahoney, C. R., Lieberman, H. R., \& Taylor, H. A. (2010). Caffeine modulates attention network function. Brain \& Cognition, 72, 181-188.

Bush, G., Luu, P., \& Posner, M. I. (2000). Cognitive and emotional influences in anterior cingulate cortex. Trends in Cognitive Science, 4, 215-222.

Bush, G., Whalen, P. J., Rosen, B. R., Jenike, M. A., McInerney, S. C., \& Rauch, S. L (1998). The counting Stroop: An interference task specialized for functional neuroimaging-validation study with functional MRI. Human Brain Mapping, 6, $270-282$.

Casey, B. J., Thomas, M. L., Welsh, T. F., Badgaiyan, R. D., Eccard, C. H., Jennings, J. R., et al. (2000). Dissociation of response conflict, attentional selection, and expectancy with fMRI. Proceedings of the National Academy of Sciences of the United States of America, 97, 8728-8733.

Corbetta, M., Kincade, J. M., Ollinger, J. M., McAvoy, M. P., \& Shulman, G. L. (2000) Voluntary orienting is dissociated from target detection in human posterior parietal cortex. Nature Neuroscience, 3, 292-297.

Coull, J. T., Frith, C. D., Frackowiak, R. S., \& Grasby, P. M. (1996). A fronto-parietal network for rapid visual information processing: A PET study of sustained attention and working memory. Neuropsychologia, 34(11), 1085-1095.

Cropley, V. L., Fujita, M., Innis, R. B., \& Nathan, P. J. (2006). Molecular imaging of the dopaminergic system and its association with human cognitive function. Biological Psychiatry, 59, 898-907.

Culm-Merdek, K. E., von Moltke, L. L., Harmatz, J. S., \& Greenblatt, D. J. (2005) Fluvoxamine impairs single-dose caffeine clearance without altering caffeine pharmacodynamics. British Journal of Clinical Pharmacology, 60, 486-493.

Daval, J.-L., von Lubitz, D. K. J. E., Deckert, J., Redmond, D. J., \& Marangos, P. J. (1989) Protective effect of cyclohexyladenosine on adenosine A1-receptors, guanine nucleotide and forskolin binding sites following brain ischemia: A quantitative autoradiographic study. Brain Research, 491, 212-226.

De Jong, R., Liang, C. C., \& Lauber, E. (1994). Conditional and unconditional automaticity: A dual process model of effects of spatial stimulus-response correspondence. Journal of Experimental Psychology: Human Perception and Performance, 30, 731-750. 
Fan, J., Flombaum, J. I., McCandliss, B. D., Thomas, K. M., \& Posner, M. I. (2003) Cognitive and brain consequences of conflict. NeuroImage, 18(1), 42-57.

Fan, J., McCandliss, B. D., Fossella, J., Flombaum, J. I., \& Posner, M. I. (2005). The activation of attentional networks. NeuroImage, 26(2), 471-479.

Fan, J., McCandliss, B. D., Sommer, T., Raz, A., \& Posner, M. I. (2002). Testing the efficiency and independence of attentional networks. Journal of Cognitive Neuroscience, 14, 340-347.

Fastbom, J., Post, C., \& Fredholm, B. B. (1990). Antinociceptive effects and spinal distribution of two adenosine receptor agonists after intrathecal administration. Pharmacology and Toxicology, 66, 69-72.

Ferre, S., Fredholm, B. B., Morelli, M., Popoli, P., \& Fuxe, K. (1997). Adenosinedopamine receptor-receptor interactions as an integrative mechanism in the basal ganglia. Trends in Neuroscience, 20, 482-487.

Fillmore, M. T., \& Rush, C. R. (2002). Impaired inhibitory control of behavior in chronic cocaine users. Drug and Alcohol Dependence, 66, 265-273.

Fine, B. J., Kobrick, J. L., Lieberman, H. R., Marlowe, B., Riley, R. H., \& Tharion, W. J. (1994). Effects of caffeine or diphenhydramine on visual vigilance. Psychopharmacology, 114, 233-238.

Fink, J. S., Weaver, D. R., Rivkees, S. A., Peterfreund, R. A., Pollack, A., Adler, E. M. et al. (1992). Molecular cloning of the rat A2 adenosine receptor: Selective coexpression with D2 dopamine receptors in rat striatum. Molecular Brain Research, 14, 186-195.

Fredholm, B. B. (1980). Are methylxanthine effects due to antagonism of endogenouos adenosine? Trends in Pharmacological Science, 1, 129-132.

Fredholm, B. B. (1995). Astra Award Lecture. Adenosine, adenosine receptors and the actions of caffeine. Pharmacology and Toxicology, 76, 93-101.

Fredholm, B., Bättig, K., Holmén, J., Nehlig, A., \& Zvartau, E. (1999). Actions of caffeine in the brain with special reference to factors that contribute to its widespread use. Pharmacology Reviews, 51, 83-133.

Frewer, L. J., \& Lader, M. (1991). The effects of caffeine on two computerized tests of attention and vigilance. Human Psychopharmacology, 6, 119-128.

García-Cabezas, M. A., Rico, B., Sánchez-González, M. A., \& Cavada, C. (2007). Distribution of the dopamine innervation in the macaque and human thalamus. NeuroImage, 34, 965-984.

Garrett, B. E., \& Griffiths, R. R. (1997). The role of dopamine in the behavioral effects of caffeine in animals and humans. Pharmacology, Biochemistry, and Behavior, 57, 533-541.

Hasenfratz, M., \& Battig, K. (1992). Action profiles of smoking and caffeine: Stroop effect, EEG and peripheral physiology. Pharmacology, Biochemistry, and Behavior, 42, 155-161.

IOM (2001). Institute of medicine. Committee on military nutrition research, food and nutrition board, institute of medicine. Caffeine for the sustainment of mental task performance. Formulations for military operations. Washington, DC: National Academy Press.

Juliano, L. M., \& Griffiths, R. R. (2004). A critical review of caffeine withdrawal: Empirical validation of symptoms and signs, incidence, severity, and associated features. Psychopharmacology, 176(1), 1-29.

Kenemans, J. L., \& Lorist, M. M. (1995). Caffeine and selective visual processing. Pharmacology, Biochemistry, and Behavior, 52, 461-471.

Kenemans, J. L., \& Verbaten, M. N. (1998). Caffeine and visuo-spatial attention. Psychopharmacology, 135, 353-360.

Kenemans, J. L., Weileman, J. S., Zeegers, M., \& Verbaten, M. N. (1999). Caffeine and stroop interference. Pharmacology, Biochemistry, and Behavior, 63(4), 589-598.

Ko, J. H., Ptito, A., Monchi, O., Cho, S. S., Van Eimeren, T., Pellecchia, G., et al. (2009). Increased dopamine release in the right anterior cingulate cortex during the performance of a sorting task: A [11C]FLB 457 PET study. NeuroImage, 46(2), $516-521$.

Koelega, H. S. (1993). Stimulant drugs and vigilance performance: A review. Psychopharmacology, 111, 1-16.

Koppelstaetter, F., Poeppel, T. D., Siedentopf, C. M., Ischebeck, A., Verius, M., Haala, I., et al. (2008). Does caffeine modulate verbal working memory processes? An fMRI study. NeuroImage, 39(1), 492-499.

Lane, J. D., \& Phillips-Bute, B. G. (1998). Caffeine deprivation affects vigilance performance and mood. Physiology \& Behavior, 65, 171-175.

Lidow, M. S., Goldman-Rakic Rakic, P., \& Innis, R. B. (1989). Dopamine D2 receptors in the cerebral cortex: Distribution and pharmacological characterization with $\left[{ }^{3} \mathrm{H}\right]$ raclopride. Proceedings of the National Academy of Sciences, 86, 64126416.

Lieberman, H. R. (1992). Caffeine. Factors affecting human performance. In D. Jones \& A. Smith (Eds.). The physical environment (Vol. II). London: Academic Press.

Lieberman, H. R. (2001). The effects of ginseng, ephedrine, and caffeine on cognitive performance, mood, and energy. Nutrition Reviews, 59(4), 91-102.

Lieberman, H. R., Tharion, W. J., Shukitt-Hale, B., Speckman, K. L., \& Tulley, R. (2002). Effects of caffeine, sleep loss, and stress on cognitive performance and mood during U.S. Navy SEAL training. Sea-air land. Psychopharmacology, 164(3), 250-261.

Lieberman, H. R., Wurtman, R. J., Emde, G. G., Roberts, C., \& Coviella, I. L. G. (1987) The effects of low doses of caffeine on human performance and mood. Psychopharmacology, 92, 308-312.

Logan, G. D., \& Cowan, W. B. (1984). On the ability to inhibit thought and action: A theory of an act of control. Psychological Review, 91, 295-327.

Loke, W. H. (1992). The effects of caffeine and automaticity on a visual information processing task. Human Psychopharmacology: Clinical and Experimental, 7, 379-388.

Lorist, M. M., \& Snel, J. (1997). Caffeine effects on perceptual and motor processes. Electroencephalography and Clinical Neurophysiology, 102(5), 401-413.
Lorist, M. M., Snel, J., Kok, A., \& Mulder, G. (1994). Influence of caffeine on selective attention in well-rested and fatigued subjects. Psychophsiology, 31(6), 525-534.

Lorist, M. M., Snel, J., Kok, A., \& Mulder, G. (1996). Acute effects of caffeine on selective attention and visual search processes. Psychophysiology, 33(4), 354-361.

Lorist, M. M., \& Tops, M. (2003). Caffeine, fatigue and cognition. Brain \& Cognition, $53,82-94$.

Lumme, V., Aalto, S., Ilonen, T., Någren, K., \& Hietala, J. (2007). Dopamine D2/D3 receptor binding in the anterior cingulate cortex and executive functioning. Psychiatry Research: Neuroimaging, 156, 69-74.

Mac Donald, A. W., Cohen, J. D., Stenger, V. A., \& Carter, C. S. (2000). Dissociating the role of dorsolateral prefrontal and anterior cingulate cortex in cognitive control. Science, 288, 1835-1838.

Malinauskas, B. M., Aeby, V. G., Overton, R. F., Carpenter-Aeby, T., \& Barber-Heidal, K. (2007). A survey of energy drink consumption patterns among college students. Nutrition Journal, 6.

Marrocco, R. T., \& Davidson, M. C. (1998). Neurochemistry of attention. In R. Parasuraman (Ed.), The attentive brain (pp. 35-50). Cambridge, MA: Massachusetts Institute of Technology Press.

Marrocco, R. T., Witte, E. A., \& Davidson, M. C. (1994). Arousal systems. Current Opinion in Neurobiology, 4, 166-170.

Mayer, J. D., \& Gaschke, Y. N. (1988). The experience and meta-experience of mood. Journal of Personality and Social Psychology, 55, 102-111.

McCusker, R. R., Goldberger, B. A., \& Cone, E. J. (2003). Caffeine content of specialty coffees. Journal of Analytical Toxicology, 27(7), 520-522.

Mitchell, P. J., \& Redman, J. R. (1992). Effects of caffeine, time of day and user history on study-related performance. Psychopharmacology, 109, 121-126.

Monsell, S. (2003). Task switching. Trends in Cognitive Sciences, 7, 134-140.

Nehlig, A. (1999). Are we dependent upon coffee and caffeine? A review on human and animal data. Neuroscience and Biobehavioral Reviews, 23, 563-576.

Nehlig, A., Daval, J. L., \& Debry, G. (1992). Caffeine and the central nervous system: Mechanisms of action, biochemical, metabolic and psychostimulant effects. Brain Research Reviews, 17, 139-170.

Neuhaus, A. H., Koehler, S., Opgen-Rhein, C., Urbanek, C., Hahn, E., \& Dettling, M. (2007). Seletive anterior cingulate cortex deficit during conflict solution in schizophrenia: An event-related potential study. Journal of Psychiatric Research, 41, 635-644.

Popoli, P., Reggio, R., Pezzola, A., Fuxe, K., \& Ferré, S. (1998). Adenosine A1 and A2A receptor antagonists stimulate motor activity: Evidence for an increased effectiveness in aged rats. Neuroscience Letters, 251, 201-204.

Posner, M. I. (1990). Hierarchical distributed networks in the neuropsychology of selective attention. In A. Caramazza (Ed.), Cognitive neuropsychology and neurolinguistics (pp. 187-210). Hillsdale, NJ: Lawrence Erlbaum.

Posner, M. I. (2004). Cognitive neuroscience of attention. New York, NY: Guilford Press.

Posner, M. I., \& Rothbart, M. K. (2005). Influencing brain networks: Implications for education. TRENDS in Cognitive Sciences, 9, 99-103.

Redick, T. S., \& Engle, R. W. (2006). Working memory capacity and attention network test performance. Applied Cognitive Psychology, 20, 713-721.

Reissig, C. J., Strain, E. C., \& Griffiths, R. R. (2009). Caffeinated energy drinks - A growing problem. Drug and Alcohol Dependence, 99, 1-10.

Sánchez-González, M. A., García-Cabezas, M. A., Rico, B., \& Cavada, C. (2005). The primate thalamus is a key target for brain dopamine. Journal of Neuroscience, 25 , 6076-6083.

Sawaguchi, T., \& Goldman-Rakic, P. S. (1991). D1 dopamine receptors in prefrontal cortex: Involvement in working memory. Science, 251, 947-950.

Sawaguchi, T., \& Goldman-Rakic, P. S. (1994). The role of D1-dopamine receptors in working memory: Local injections of dopamine antagonists into the prefrontal cortex of rhesus monkeys performing an oculomotor delayed-response task. Journal of Neurophysiology, 71, 515-528.

Smith, A. (2002). Effects of caffeine on human behavior. Food and Chemical Toxicology, 40, 1243-1255.

Smits, P., Boekema, P., DeAbreu, R., Thien, T., \& van't Laar, A. (1987). Evidence for an antagonism between caffeine and adenosine in the human cardiovascular system. Journal of Cardiovascular Pharmacology, 10(2), 136-143.

Snel, J., Lorist, M. M., \& Tieges, Z. (2004). Coffee, caffeine, and cognitive performance. In A. Nehlig (Ed.). Boca Raton, Fl: CRC Press.

Spiller, G. (Ed.). (1997). Caffeine. Boca Raton, Fl: CRC Press.

Solinas, M., Ferré, S., You, Z. B., Karcz-Kubicha, M., Popoli, P., \& Goldberg, S. R. (2002). Caffeine induces dopamine and glutamate release in the shell of the nucleus accumbens. The Journal of Neuroscience: The Official Journal of the Society for Neuroscience, 22(15), 6321-6324.

Statland, B. E., \& Demas, T. J. (1980). Serum caffeine half-lives. Healthy subjects vs. patients having alcoholic hepatic disease. American Journal of Clinical Pathology, 73, 390-393.

Tassin, J. P., Bockaert, J., Blanc, G., Stinus, L., Thierry, A. M., Lavielle, S., et al. (1978). Topographical distribution of dopaminergic innervation and dopaminergic receptors of the anterior cerebral cortex of the rat. Brain Research, 154,241-251.

Tieges, Z., Ridderinkhof, K. R., Snel, J. \& Kok, A. (2004). Caffeine strengthens action monitoring: Evidence from the error-related negativity. Cognitive Brain Research, 21(1), 87-93.

Tieges, Z., Snel, J., Kok, A., Plat, N., \& Ridderinkhof, K. R. (2007). Effects of caffeine on anticipatory control processes: Evidence from a cued task-switch paradigm. Psychophysiology, 44(4), 561-578.

Tieges, Z., Snel, J., Kok, A., \& Ridderinkhof, J. R. (2009). Caffeine does not modulate inhibitory control. Brain \& Cognition, 69, 316-327. 
Tieges, Z., Snel, J., Kok, A., Wijnen, J. G., Lorist, M., \& Ridderinkhof, K. R. (2006). Caffeine improves anticipatory processes in task switching. Biological Psychology, 73, 101-113.

Varani, K., Portaluppi, F., Merighi, S., Ongini, E., Belardinelli, L., \& Borea, P. A. (1999). Caffeine alters A2A adenosine receptors and their function in human platelets. Circulation, 99, 2499-2502.
Wesensten, N. J., Killgore, W. D. S., \& Balkin, T. J. (2005). Performance and alertness effects of caffeine, dextroamphetamine, and modafinil during sleep deprivation. Journal of Sleep Research, 14, 255-266.

Williams, G. V., \& Goldman-Rakic, P. S. (1995). Modulation of memory fields by dopamine D1 receptors in prefrontal cortex. Nature, 376, 572-575. 